\title{
非特異性尿路感染症
}

\section{I 脊損患者の尿路感染症の臨床的特徵}

$\begin{array}{lllll} & \text { 近 } & \text { 藤 } & & \text { 賢 } \\ \text { 関東労災病院泌尿器科 } & \text { 梶 } & \text { 由 } & \text { 一 } & \text { 之 } \\ & \text { 三 } & \text { 木 } & \text { 信 } & \text { 男 }\end{array}$

\section{NONSPECIFIC INFECTION OF THE URINARY TRACT : \\ I CLINICAL ASPECTS OF THE URINARY TRACT INFECTIONS IN TRAUMATIC PARAPLEGICS}

\author{
Masaru Kondo, Kazuyuki Kazita and Nobuo Miki
}

From The Department of Urology, Kanto-Rohsai Hospital, Kawasaki, Kanagawa

\section{I 緒 言}

脊鹃道損傷の急性ショック期或は回復慢性期の何れの時 期においても非特異性尿路感染症注直接に又間接に腎不 全学進行させる原因として極めて重要な合併症である。

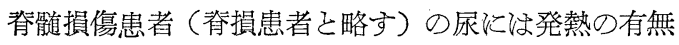
にかかわらず沢山の白血球及び細菌定認めることが多 い. 無熱で膿尿・細菌尿のある時は非特異性尿路感染症 の慢性型，有熱で膿尿・細菌尿があり且つ尿路以外に発 熱の原因が認められぬ時はその急性型と考えることにす る.

急性型の場合解熱过しめることはさして困難なととで はないが，沓中の白血球及び細菌学消失させるとさ注容 易でなく, たこえ消失させるここが出来ても間もなく再 び感染をおこし，慢性型に移行することが多い。

慢性型の場合病的所見ほ殆んご膿尿こ細菌尿だけのこ とが多い. この膿尿細菌尿学根治させることは現在の抗 菌性薬剂を充分に使用しても仲从困難である.

脊損患者借合併する非特異性尿路感染症が難治な理由

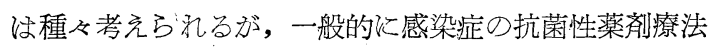
が奏効せぬ理由としてあげられている感染菌の耐性獲 得, 菌交代, 混合感染, 再感染, 投与薬凧の抗菌作用が 感染菌洷達しがたいような条件の存在, 或は感染防禦 力の低下等で充分説明しうる様である.もし上記の理由 で猆損患者の非特異性尿路感染症の難治な原因が説明さ れるとするならばそれらの原因のうちの何れが臨床上最 も重要であるか評価するととが必要となつてくる。簃
密にいうならばかかる評価を行うととは現状に怙いては 不可能ともいえょう。しかし臨床的にそれらの重要度を 推定し, 治療法の改善試及ることは必ずしも不可能で なく是非必要なとここ思われる。

この様な考无から当院入院中の脊損患者の尿路感染菌 について行つた細菌学的検查の成績 整理し, 而性獲 得, 菌交代, 混合感染, 再感染等の要因がごの程度に関 与しているかを検討すると同時に今後に残された問題学 出来るだけ明確にしょうと若干の考察定試みた。

\section{II 尿路感染菌の構成}

(1) 同定検查 :

腸内細菌の同定のために (i) Kligler 培地, (ii) SM 培地, (iii) クエン酸ナトリウム培地, (iv) SIM 培 地，（v）ブドウ糖燐酸塩ペプン水，（vi）尿素培地 を, 球菌の同定に Staphylococcus 培地 110 を用いた。

第 1 表，尿路感染菌の種類

\begin{tabular}{|l|c|c|}
\hline \multicolumn{1}{|c|}{ 分 } & 症例数 & 分離回数 \\
\hline Escherichia & 14 & 23 \\
\hline Citrobacter & 6 & 14 \\
\hline Klebsiella & 2 & 2 \\
\hline Proteus & 30 & 62 \\
\hline Providencia & 3 & 4 \\
\hline 菌 型 不 明 桿 菌 & 3 & 4 \\
\hline Pseudomonas & 7 & 20 \\
\hline Staphylococcus albus & 20 & 28 \\
\hline Staphylococcus aureus & 17 & 29 \\
\hline
\end{tabular}


第 2 表 尿路感染菌の構成（A群） 1 ～ 3 週間

\begin{tabular}{|c|c|c|c|c|c|c|c|c|c|c|c|c|c|c|c|c|c|c|}
\hline 例 & 1 & 2 & 3 & 4 & 5 & 6 & 7 & 8 & 9 & 10 & 11 & 12 & 13 & 14 & 15 & 16 & 17 & 18 \\
\hline 検 查 回 数 & 2 & 2 & 3 & 3 & 2 & 2 & 2 & 2 & 2 & 3 & 3 & 2 & 3 & 3 & 3 & 3 & 3 & 3 \\
\hline Escherichia & 2 & & & & & & & & 2 & & & 1 & & & 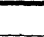 & 1 & 2 & \\
\hline Citrobacter & & & & & & & & & & & & & 2 & & & & & 2 \\
\hline Klebsiella & & & & & & & & & & & & & & & 1 & & & \\
\hline Proteus & & 2 & 3 & & 2 & 2 & 2 & 2 & & 2 & 2 & 1 & 1 & 1 & 2 & & 1 & 1 \\
\hline Providencia & & & & & & & & & & & & & & 1 & & & & \\
\hline 菌型不明桿菌 & & & & & & & & & & & & & & & & 2 & & \\
\hline Pseudomonas & & & & 3 & & & & & & & & & & 1 & & & & \\
\hline Staph. albus & & & & & 2 & 1 & 1 & & & & & 2 & & 1 & 1 & & & 2 \\
\hline Staph. aureus & & & & & & & & 1 & 1 & & & & 1 & & & 1 & & \\
\hline 增菌陰性 & & & & & & & & & & 1 & 1 & & & & & & & \\
\hline
\end{tabular}

第 3 表 尿路感染菌の構成（B 群） $1 \sim 3$ 月

\begin{tabular}{|c|c|c|c|c|c|c|c|c|}
\hline 症例 & 1 & 2 & 3 & 4 & 5 & 6 & 7 & 8 \\
\hline 检 查回 数 & 2 & 4 & 3 & 5 & 4 & 2 & 2 & 2 \\
\hline Escherichia & & & 2 & & 2 & 1 & 1 & 1 \\
\hline \multicolumn{9}{|l|}{ Citrobacter } \\
\hline Klebsiella & & & & & & 1 & & \\
\hline Proteus & 2 & 4 & & 2 & & & 1 & 1 \\
\hline Providencia & & & & & 2 & & & \\
\hline \multicolumn{9}{|l|}{$\frac{\text { 菌型不明桿菌 }}{\text { Pseudomonas }}$} \\
\hline \multicolumn{9}{|l|}{ Pseudomonas } \\
\hline Staph. albus & & 1 & 1 & & & 1 & 1 & \\
\hline Staph. aureus & & 1 & 1 & 5 & 3 & & & \\
\hline 增菌陰性 & & & 1 & & & & & \\
\hline
\end{tabular}

第 4 表 尿路感染菌の構成（C群）4～6 月

\begin{tabular}{|l|l|l|l|l|l|l|l|l|l|l|}
\hline 症 例 & 1 & 2 & 3 & 4 & 5 & 6 & 7 & 8 & 9 & 10 \\
\hline 検 歪 回 数 & 7 & 9 & 8 & 7 & 7 & 6 & 6 & 4 & 4 & 4 \\
\hline Escherichia & & 1 & 1 & & & 5 & & & \\
\hline Citrobacter & & 2 & 3 & & 4 & & & 1 & & \\
\hline Klebsiella & & & & & & & & & & \\
\hline Proteus & 7 & 3 & 4 & 6 & 1 & & 2 & & 1 & 1 \\
\hline Providencia & & & & & 1 & & & & & \\
\hline 菌型不明棉菌 & & & & 1 & & 1 & & & & \\
\hline Pseudomonas & & 3 & & & & & 4 & 3 & 3 & 3 \\
\hline Staph. albus & 2 & 4 & & 1 & 1 & 1 & & 1 & 1 & 2 \\
\hline Staph. aureus & 1 & 2 & & 5 & 2 & 1 & 1 & & 1 & 1 \\
\hline 增 菌 陰 性 & & & & & 1 & & & & & \\
\hline
\end{tabular}

培地上の形態及びグラム染色性をみた上で上記 7 種の 培地にょり示される生化学的性質から桿菌については属 までの決定を，球菌については種季での決定を行つた。

腸内細菌の分類は1959年の Kauffman の分類に従つ た.

（2）分離菌株：

脊損 41 症例に 133 回の同定検查を行つた (第 1 表). Proteus 62回, Staphylococcus aureus 29回, Staphylococcus albus 28回, Escherichia 23回, Pseudomonas 20回, Citrobacter 14回, Providencia 4 回, 菌型不明
桿菌 4 回, Klebsiella 2 回学分離した。

（3）混合感染 :

41 症例中 1 回の同定検查しか行わなかつた 5 症例を除 いた 36 症例について 1 週乃至 6 月間に $2 \sim 9$ 回の同定検 查を行つた。 $1 \sim 3$ 週間に $2 \sim 3$ 回の検查を行つた 18 症 例学 $A$ 群 (第 2 表), $1 \sim 3$ 月間に $2 \sim 5$ 回の検査を行つ 它 8 症例学 $B$ 群 (第 3 表), $4 \sim 6$ 月間に $4 \sim 9$ 回の検查 学行つた10症例定 C群 (第 4 表) とする。

感染菌の構成に変化字認めなかつた症例淰 $\mathrm{A}$ 群で 5 例 （症例 1 5 ) $27 \% ， B$ 群では 1例（症例 1) $12 \% ， \mathrm{C}$ 
群には 1 例もない。

桿菌感染の認められなかつたととのある症例はA群に 2 例， B 群任 1 例， C 群汇 1 例あるが，A群の 2 例及び C 群の 1 例怯感染菌陰性の時を除けば毎回桿菌感染があ る. 又球菌感染が常に認められた症例汸 $\mathrm{A}$ 群に 2 例, $\mathrm{B}$ 群に 1 例で C 群にはない。

これらの成績亦ら尿路感染菌の構成注 $1 \sim 3$ 週間でも 約 $2 / 3$ の症例で変化し，長期間検查をつぶけると变化する 症例が次第に増加し，4〜6月間では全例で変化するこ と, 尿路感染菌の主要の部堂桿菌がしめるととが分る.

桿菌と球菌の混合感染梳 $\mathrm{A}$ 群で11例 $61 \%$ に，B群で 6 例75\%に，C群で 9 例 $90 \%$ 亿認められ，検查期間が長く なるに従い桿菌己球菌の混合感染学执ししたここのある 症例が増加する (第 5 表).とれら混合感染学認めた症例 に行つ検查中混合感染注 $\mathrm{A}$ 群11例27回のう 5 13 回 48 $\%$, B 群 6 例 20 回中11回 $55 \%$, C 群 9 例55回中 25 回 $45 \%$ に認められ，各群学通じて大約50\%である。

（4）菌交代 :

同定裕查を 2 回行つてその両者を比較すると（i)球菌 の女で同種, ( ii) 桿菌の及で同属, (iii) 桿菌同属, 球菌同種, (iv) 球菌のみで異種, ( v ) 桿菌同属, 球 菌異種。(vi) 桿菌のみで異属, (vii) 桿菌異属, 球菌 同種, (viii) 桿菌異属, 球菌異種, (ix) 菌消失の 9 種 類の組合せがある。乙の (i) (ii) (iii) を菌交代 (一),

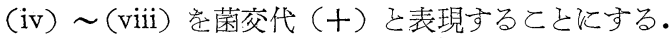
办方菌交代の有無と無処置 1 ～週群及び 2 月群, 感性薬剂群及び而性薬剂群䎲ついて検討する，薬成の投 与期間は 5〜15日である (第 6 表).

菌交代 $(+)$ はごの群であ菌交代（一）よりも多く，
第 5 表 混合感染症例

\begin{tabular}{|c|c|c|c|c|c|}
\hline & & $\begin{array}{l}\text { 混 } \\
\text { 染 }\end{array}$ & & & 合感数 \\
\hline$\overline{\mathrm{A}}$ 群 1 3 週 & 18 侈 & 1例 & $61 \%$ & $3 / 27$ & $48 \%$ \\
\hline B 群 1 〜月 & 8 例 & 6 例 & $75 \%$ & $11 / 20$ & $55 \%$ \\
\hline 群 4 〜 6 月 & 10 位 & 9 例 & $90 \%$ & $25 / 55$ & 45 \\
\hline
\end{tabular}

全体己してみると菌交代（一) 21例, 菌交代（十）36例 である. 菌消失注感性 $\mathrm{Km}$ 群 2 例, 感性 Tc 群 1 例及 び耐性 NFT 群 1 例の計 4 例である.

菌交代（一）のうち最も多いのは同属稈菌の夕の場合 であり, 菌交代 $(+)$ で注桿菌同属球菌異種, 次いで桿 菌異属球菌異種の場合である。

今回の同定検查流前述したように桿菌については属ま での, 球菌については種宗での検查しか行つていない. 従つて菌交代（一）といつても同属桿菌，同種球菌が同 定されたということしか意味しない．更に詳細な同定検 查学行えば一層多くの菌交代が認められる可能性が強 い. との点汇関し薬戍感受性の項でもう一度ふれる。

（5）菌交代の機序：

尿路感染菌の交代が赫とる機序としてね先ず外部より の新しい細菌の感染,すなわち再感染が先ず考允られる. これ证何ら亦の経尿道的操作を行つ場合以山適切であ ろう。しかしその様な操作学行わなかった回の症例に みられる菌交代の説明には適当でない. 後部尿道の常在

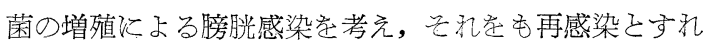
汭説明注可能である。この様な逆行性再感染を同時にリ ンパ行性，血行性感染考も考慮にいれるべきであり，又 発見しえなくても各種桿菌や球菌の混合感染があると仮 定し，何らかの理由により主要感染菌の交代が抗とつて くると考觉るととも出来る.

第 6 表 尿路感染菌の構成

\begin{tabular}{|c|c|c|c|c|c|c|c|c|c|c|c|c|}
\hline & & & 菌交个 & $(-$ & & & & 菌卒 & $+)$ & & & \\
\hline 桿 & 菌 & $(-)$ & 同 & 同 & 手 & $(-)$ & 同 & 変. & 変 & 変 & & 消 \\
\hline 球 & 菌 & 同 & $(-)$ & 同 & 計 & 変 & 変 & $(-)$ & 同 & 変 & 訫 & \\
\hline & 1 月 & 1 & 2 & 0 & & 0 & 2 & 1 & 2 & 0 & & 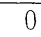 \\
\hline 無処㯰 & 2 月 & 0 & 1 & 0 & & 0 & 0 & 1 & 0 & 2 & & 0 \\
\hline & $\mathrm{K} \mathrm{m}$ & 0 & 2 & 0 & & 0 & 1 & 0 & 0 & 0 & & 2 \\
\hline 感 性 & Tc & 0 & 1 & 0 & & 0 & 1 & 0 & 0 & 2 & & 1 \\
\hline & $\mathrm{K} \mathrm{m}$ & 0 & 4 & 0 & & 0 & 4 & 1 & 0 & 0 & & 0 \\
\hline 耐 性 & $\mathrm{SMT}$ & 1 & 1 & 1 & & 0 & 6 & 2 & 0 & 1 & & 0 \\
\hline & NFT & 0 & 7 & 0 & & 0 & 5 & 0 & 0 & 5 & & 1 \\
\hline & & 2 & 18 & 1 & 21 & 0 & 19 & 5 & 2 & 10 & 36 & 4 \\
\hline
\end{tabular}


この様に種々の可能性を考慮にいれて尿路感染菌交代 の機序を明ら㡈してゆくことは極めて重要なととと思 われる。

\section{III 尿路感染菌の薬剤感受性}

（1）感受性検查 :

尿路感染菌の感受性検查のために培地ほ Blood agar を使用し, デイスクによる直接法で感受性学判定した。 ペニシリン $(\mathrm{Pe})$, ストレプトマイシン $(\mathrm{Sm})$, クロラ ムフェニコール $(\mathrm{Cp})$, テトラサイクリン $(\mathrm{Tc})$, エリス ロマイシン (Em), スルフアイソキサゾール (SIX), ス ルフアメチルチアジアゾール(SMT),オレアンドマイシ ン $(\mathrm{Om})$, カナマイシン $(\mathrm{Km})$,コリスチン $(\mathrm{Col})$ の10 種の薬剤は昭和デイスクを使用した。ニトロフラントイ ン（NFT） 汸エール社のデイスクを用い，阻止帯がデ イスク辺縁六ら $4 \mathrm{~mm}$ 乃至乞れ以上を感性，4 $\mathrm{mm}$ 以下学耐 性と判定する様にという指示に従つた。

（2）薬郕別耐性 :

脊損61症例飞尿路感染菌の感受性検査学行つた。検査 回数怔 $\mathrm{Pe}, \mathrm{Sm}, \mathrm{Cp}, \mathrm{Tc}, \mathrm{Em}, \mathrm{SIX}, \mathrm{SMT}$ の7剂につい
ては 225 231回, Om は 154回, Km, Col, NFTについ ては 101〜 119回である. 阻止帯内に扮ける菌の発育が 及られた場合任不完感性とした（第 7 表）.

耐性の発生頻度注 $\mathrm{Km} 20 \%$, Col41\%, Sm 56\%, Cp $80 \%$, Tc $81 \%$, NFT $83 \%$, Em $86 \%$, Pe $91 \%$, SIX 94\%, SMT 97\%, Om 97\%と次第信くなる.

$\mathrm{Om}$ は未使用薬郕であるから $97 \%$ 而性は尿路感染菌 の多くをしめる桿菌の自然耐性であろろ. Km, Col, NF Tも未使用薬剂であり，表の成績にば試用後の成績も若 干ふく李れているが $\mathrm{Km} 20 \%$ ，Col11\%，NFT 83\%は大 体自然耐性をみなしてよいであろう。多剂耐性菌尿路感 染症治療によいといわれている NFTに対する耐性の発 生頻度が高いのは意外であつた。

（3）多剂耐性：

11種の薬剤に対する感受性を春損50症例について検査

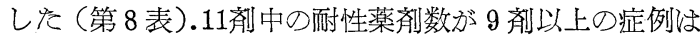
50 例中 30 例 $60 \%$ ．6剂以上の症例住 45 例 $90 \%$ である。す なわち11剂中 6 剂以上飞耐性をもつ症例が $90 \%$ をしる という強い多剤而性がみとめられる。

第 7 表 尿路感染菌の薬剤感受性

\begin{tabular}{|l|r|r|r|r|r|r|r|r|r|r|r|}
\hline & $\mathrm{Pe}$ & $\mathrm{S} \mathrm{m}$ & $\mathrm{Cp}$ & $\mathrm{Tc}$ & $\mathrm{E} \mathrm{m}$ & $\mathrm{S} \mathrm{I} \mathrm{X}$ & $\mathrm{S} \mathrm{M} \mathrm{T}$ & $\mathrm{O} \mathrm{m}$ & $\mathrm{K} \mathrm{m}$ & $\mathrm{Col}$ & $\mathrm{N} \mathrm{F} \mathrm{T}$ \\
\hline 検査回数 & 226 & 226 & 226 & 226 & 226 & 225 & 231 & 154 & 119 & 101 & 110 \\
\hline 感性 & 20 & 92 & 39 & 39 & 27 & 12 & 7 & 8 & 81 & 46 & 18 \\
\hline 不完感性 & 0 & 8 & 6 & 4 & 4 & 2 & 1 & 0 & 14 & 14 & 1 \\
\hline 恧 性 & 206 & 126 & 181 & 183 & 195 & 211 & 223 & 146 & 24 & 41 & 91 \\
\hline 而性率\% & 91 & 56 & 80 & 81 & 86 & 94 & 97 & 97 & 20 & 41 & 83 \\
\hline
\end{tabular}

第 8 表 多剂耐性

\begin{tabular}{|c|c|c|c|c|c|c|}
\hline $\begin{array}{l}11 \text { 剂中 } \\
\text { 耐性薬 } \\
\text { 剂数 }\end{array}$ & $\begin{array}{l}1 \text { 年 } \\
\text { 未満 }\end{array}$ & $\begin{array}{l}1 \sim \\
2 \text { 年 }\end{array}$ & $\begin{array}{l}2 \text { 〜 } \\
3 \text { 年 }\end{array}$ & 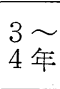 & $\begin{array}{l}5 \text { 年 } \\
\text { 以上 }\end{array}$ & 計 \\
\hline 11 & 1 & 1 & 0 & 0 & 0 & 2 \\
\hline 10 & 1 & 5 & 1 & 3 & 1 & 11 \\
\hline 9 & 4 & 6 & 2 & 2 & 3 & 17 \\
\hline 8 & 1 & 1 & 1 & 2 & 0 & 5 \\
\hline 7 & 0 & 1 & 2 & 1 & 1 & 5 \\
\hline 6 & 1 & 0 & 2 & 2 & 0 & 5 \\
\hline 5 & 0 & 0 & 0 & 1 & 0 & 1 \\
\hline 4 & 0 & 0 & 0 & 1 & 0 & 1 \\
\hline 3 & 0 & 0 & 1 & 0 & 0 & 1 \\
\hline 2 & 1 & 0 & 0 & 0 & 0 & 1 \\
\hline 1 & 0 & 0 & 0 & 1 & 0 & 1 \\
\hline 0 & 0 & 0 & 0 & 0 & 0 & 0 \\
\hline 計 & 9 & 14 & 9 & 13 & 5 & 50 \\
\hline
\end{tabular}

受傷後の経過年数別に多剤耐性の頻度をみると 9 用以 上の耐性は受傷後 1 年未満では 9 例中 6 例, $1 \sim 2$ 年で は 14 例中 12 例， 5 年以上では 5 例中 4 例で60 80\%をし めているが, 受傷後 $2 \sim 3$ 年では 9 例中 3 例, $3 \sim 4$ 年 では13例中 5 例で30 40\%にすぎない。 6 剂以下の耐性 は受傷後 1 年未満では 9 例中 2 例， $1 \sim 2$ 年では 14 例中 1 例，5 年以上では 5 例中 1 例で $20 \%$ 以下であるが，受 傷後 $2 \sim 3$ 年では 9 例中 5 例, $3 \sim 4$ 年では 13 例中 6 例 で50\%前後である.すなわち受傷後 2 年未満及び 5 年以 上の症例に治強い多郕耐性がみられるが, 受傷後 2〜4 年の症例の耐性はそれ鿌ででない，との成績から早急に 結論を導くことは避けるべきであろうが, 受傷後の種々 の機会に化学潦法剤や抗生物質を濫用するために尿路感 染菌が次第に耐性学獲得してゆくこいう漸進的耐性獲得 の仮定に対しては否定的である. 
（4）耐性薬郕数の変化 :

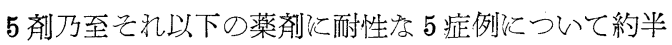
年にわたる感受性検查の成績を順にならへてみるを耐性 薬郕数の減少が認められる(第 9 表).症例 1 では 5 削か ら 2 用に, 症例 3 では 6 剂办ら 5 剂化, 症例 4 では 6 剂

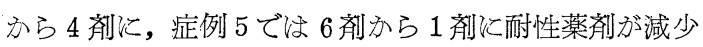
している.

第 9 表 5 㓮以下に耐性の症例

\begin{tabular}{|c|c|c|}
\hline 症例 & 受傷後年数 & 耐性薬剂数/検査薬郕数 \\
\hline 1 & 1 年未満 & $5 / 7 \rightarrow 4 / 7 \rightarrow 2 / 11$ \\
\hline 2 & 2 年 8 月 & $3 / 11$ \\
\hline 3 & 4 年11月 & $5 / 11$ \\
\hline 4 & 3 年 3 月 & $4 / 7 \rightarrow 3 / 7 \rightarrow 6 / 8 \rightarrow 4 / 11$ \\
\hline 5 & 3 年 3 月 & $4 / 7 \rightarrow 6 / 8 \rightarrow 1 / 11$ \\
\hline
\end{tabular}

薬刜投与による耐性薬郕の増加は衆知の事実であるが 耐性薬凨の減少は今迄殆んご指摘されたことがない・こ の様な耐性薬剤の減少が同一感染菌の附性喪失意味す るつか或は耐性の異る菌と交代するとと意味するかは
不明であるが，デイスク法による感受性検查の成績にも

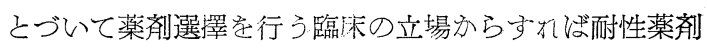
数の減少は極めて好都合なととである.

かかる耐性薬剤数の減少が又増加がごの様な条件のも そに扢とるかを菌交代 (一) 群及び菌交代 (十) 群につ き, 又無処置群, 感性薬剤投与群及び而性薬郕投与群に つき検討を行う.

(i) 菌交代 (一) 群

菌交代 (一) の21症例惊無処置群 4 例, 感性薬剂投与 群 3 例, 耐性薬郕投与群14例である (第10表).

2 回の感受性検查を比較して感受性に变化のない症例 は各群を通じて 1 例もない. 而性の減少安認めを郕数安 I , 堌加を認めた剂数を D とし $\mathrm{I} / \mathrm{D}$ 亿う比学求めると 無処置群及び感性 Tc 群社 0 , 感性 $\mathrm{Km}$ 群 2.6 ,

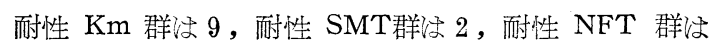
1.1である。

(ii) 菌交代 (十) 群

菌交代 (十) の36症例炇無処置 $1 \sim 3$ 週群 5 例, 2 月 群 3 例, 感性薬荗群 4 例, 耐性薬郕群 24 例である“（第11

第10表 菌交代 (一)

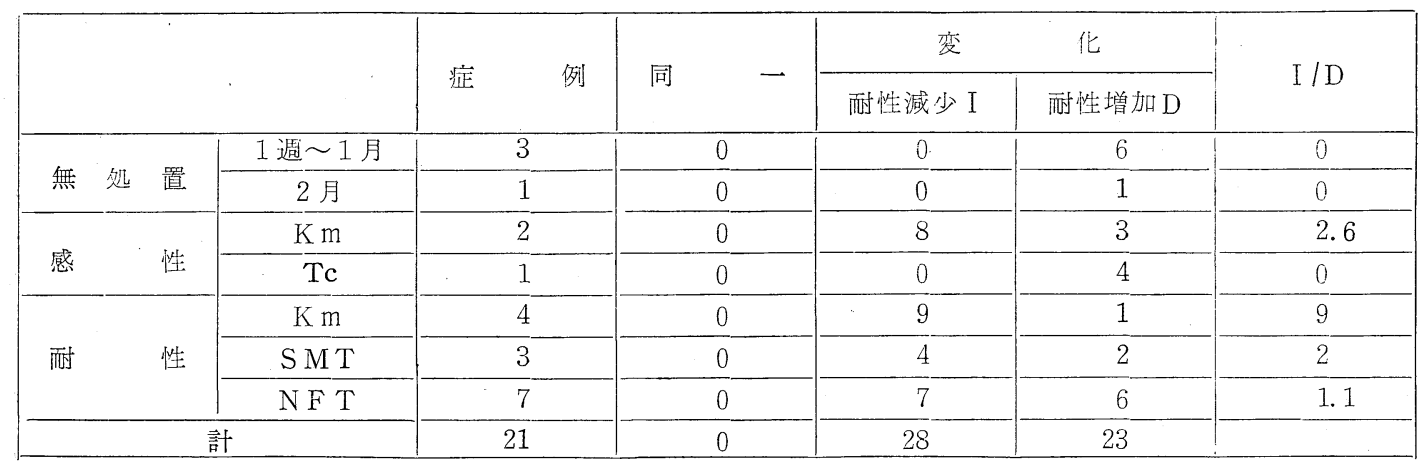

第11表 菌交代 (+)

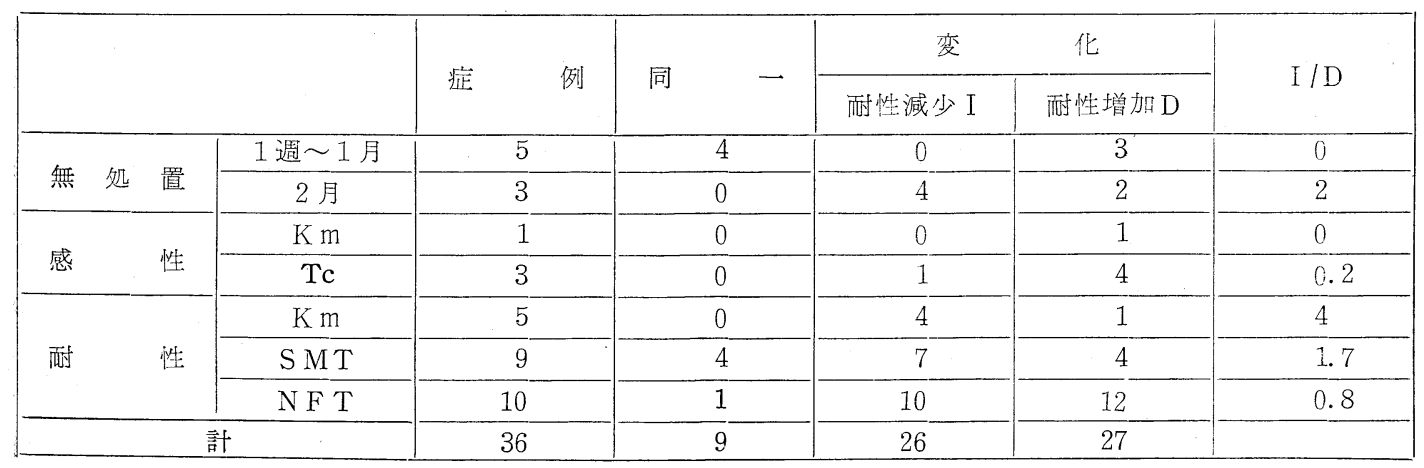


表).

感受性の变化のない症例活無処置 1 ～週群 4 例, 耐 性 SMT 群 4 例, 而性 NFT 群 1 例の計 9 例である. 残る27例では感受性が変化しているので菌交代 (一) 群 己同様に I/D学求めると無処置 1 ～週群及び感性 $\mathrm{Km}$

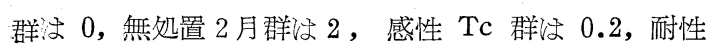
$\mathrm{Km}$ 群以 4 , 耐性 SMT 群以 1.7, 耐性 NFT 群は 0.8 である。

(iii) 使用薬郕による I/D 比：

而性減少の剂数 I と增加の剂数 D と方ら求めた I/D比 队 1 以上の時浽耐性薬刻数学減少させる傾向が強い ことを, 1 以下の時には増加させる傾向が強いこと意 味している. このI/D比蒾交代の有無別に, 又使用薬

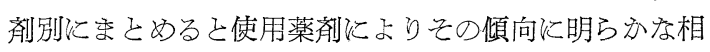
違方ることが分る(第12表).

第12表 感受性の I / D

\begin{tabular}{|c|c|c|c|c|}
\hline & \multicolumn{2}{|c|}{\begin{tabular}{|c|c|} 
䒩交代(一菌交代(+) \\
21 例
\end{tabular}} & 計57例 \\
\hline \multirow[b]{2}{*}{ 無処置 } & 1 過〜 1 月 & 0 & 0 & 0 \\
\hline & 2 月 & 0 & 2 & 1.3 \\
\hline \multirow[b]{2}{*}{ 感 性 } & $\mathrm{Km}$ & 2.6 & 0 & 2 \\
\hline & Tc & 0 & 0.2 & 0.1 \\
\hline \multirow{3}{*}{ 耐，性 } & $\mathrm{K} \mathrm{m}$ & 9 & 4 & 6.5 \\
\hline & $\overline{S M T}$ & 2 & 1.7 & 1.8 \\
\hline & NFT & 1.1 & 0.8 & 0.9 \\
\hline
\end{tabular}

菌交代の有無によらず $\mathrm{I} / \mathrm{D}$ 比が 1 以上なのは耐性 $\mathrm{Km}$ 及び耐性 SMT 群である. 又無処置群の I/D 比 $0 \sim$ 1.3 より大きいの注感性 $\mathrm{Km}$ 群 2 , 耐性 $\mathrm{Km}$ 群 6.5, 耐性 SMT 群 1.8 であり, 感性 Tc 群 0.1 , 而性NFT 群 0.9 無処置群の範囲内である。すなわち感性及び耐 性 $\mathrm{Km}$, 而性 SMT 投与は尿路感染菌の耐性剂数学減少 させる傾向が強く, 感性 Tc 及び而性 NFT 投与注耐性 㓮数定減少させる傾向があると注いい難い，以上の成績 ふらみればかかる傾向の相異は非常にはつきりして拉 り，少数例亦らえられた偶然にもこづくものではないか こいう疑問もあるが, 薬昘の性質によるものではないか と思わせる。

（5）耐性獲得及び伝達 :

生体内に扔ける感染菌の耐性化は薬剤の間接乃至直接 の作用による (1) mutation \& selectionと (2) adaptation or induction が同時に或はいづれかが主役を演 じて行われると考えられている。し办し薬郕投与により 感染菌が次第に耐性学獲得してゅくというとと結核
症に対する $\mathrm{Sm}$ 投与時の結核菌以外飞は証明されてい ない. 従つて非特異性尿路感染菌の耐性獲得の機序は mutation \& selectionによるという見解が現在の定説と いえよう. この様な遺伝的な突然变異による耐性の獲得 (mutation) 及び特殊な環境のも己に而性獲得菌が残 存増殖する (selection) という立場分らす机ば感受性が 異なるこ己は菌株が異なること意味する。むしての見 解が正しいとすれば同定検查で菌交代（一）とされた症 例で感受性の変化のない例が 1 例もなかつたことは全例 に菌交代があつたととを示している。

現在の定説である mutation \& seletionの立場方ら菌 交代（十）で感受性同一の症例があること定説明するの は仲々困難である。乙视多剂耐性赤痢菌汇関し秋葉・ 三橋・渡辺・落合等によりなされた腸内細菌相互間にお ける耐性の直接伝達という考方方導大する己容易侻 明がつく. 尿路感染菌洁腸内細菌科の桿菌が多く, し 亦も混合感染空していると推測される亦万尿路感染菌 相互間炕細菌性赤瘌の研究で確方められた耐性の直接伝 達が行われているこ仮定してむそれ㴽ざ無理ではなかる

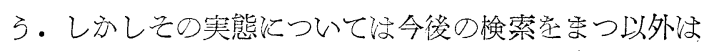
ない.

\section{IV 耐性薬剤投与}

感染症の治療に抗菌性薬郕学使用する適応浪患では なく特定の細菌による感染である.従つて感染菌の薬訪 感受性をしらべ感性薬剤を筫擇投与するここが抗菌性薬

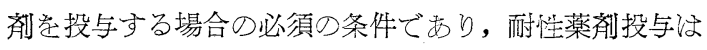
禁忌乞されている. 非特異性尿路感染症の治療も当然こ の基本的原則に従つて行うべきであるこされている.

春損患者の非特異性尿路感染症に扔いて頻回の尿路感 染菌の交代, 耐性薬剤の変動が 久られることに既にのべ

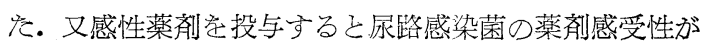
変化し, 感性薬郕もすぐ们耐性薬剤乞なつてし末う。従 つて非特異性尿路感染症に耐性薬剂投与が本当に禁忌で あるならば抗菌性薬郕の投与は行わない万がよいといえ 上う. 大体耐性薬用投与注禁忌さいわれているが, 非特 異性尿路感染症の場合ざの様な不都合が生ずるのである ろ办. その点について脊損患者の非特異性尿路感染症に 無意識に或々意識して而性薬郕投与を行つた成績学無処 置時及び感性薬郕投与時の成績亡比較検討した。

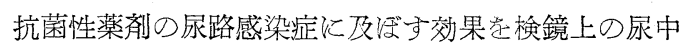
白血球及び細菌の增減から観察した。すなわ年尿路感染 症に打注生体反応の消長学尿中白血球数で, 細菌の活 動性穵尿中細菌数でみた. そうして比較の都合上白血球, 
第13表 尿中白血球・細菌の検鏡所見

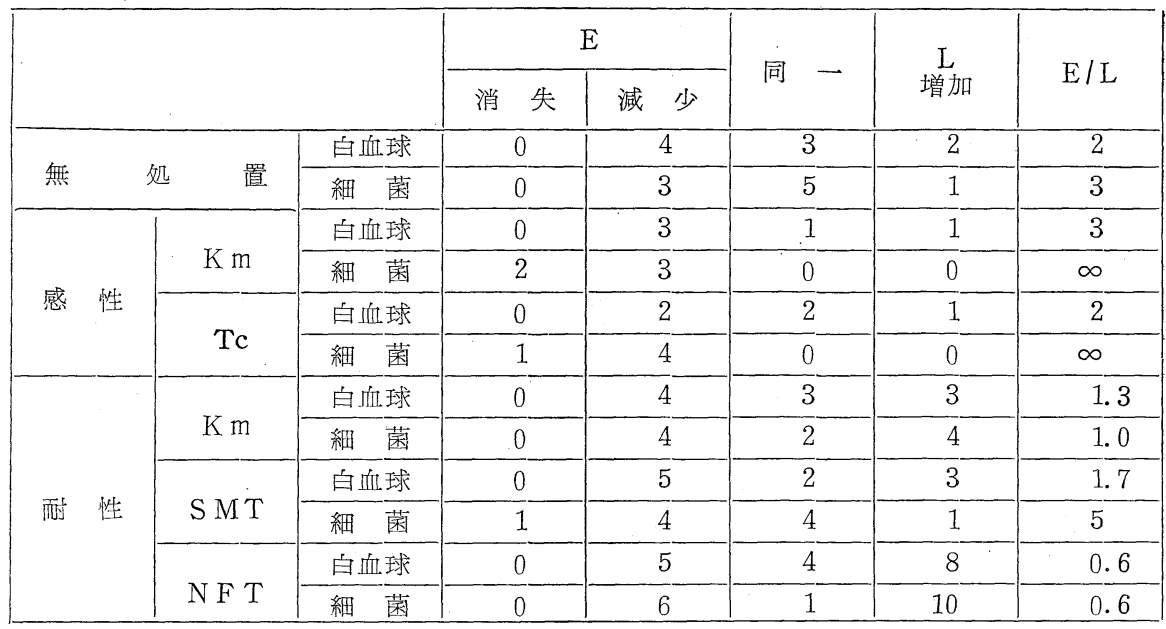

細菌の消失乃至減少を認めた症例数 $\mathrm{E}$ 己増加を認めを症 例数工と亦ら $\mathrm{E} / \mathrm{L}$ こいう比白血球，細菌のそれぞれ について求めた，乙の比は大きい程分子である消失減少 症例数が増加症例数にくらべ多いととを意味する.

無処置時の白血球の $\mathrm{E} / \mathrm{L}$ 注 2 , 細菌の $\mathrm{E} / \mathrm{L}$ は 3 で ある・と机学 $(2 ， 3)$ と表現するとこにすれば感性 $\mathrm{Km}(3, \infty)$, 感性 $\mathrm{Tc}(2$, , ), 而性 $\mathrm{Km}(1.3,1.0)$, 而性 SMT $(1.7,5)$, 耐性 NFT $(0.6,0.6)$ である (第13表). 無処置時と比較して有効なのは感性 $\mathrm{Km}$, 感 性 Tc 及び耐性 SMT の3 種であり, 耐性 $\mathrm{Km}$, 耐性 NFT は有害である。

尿中白血球及び細菌の $\mathrm{E} / \mathrm{L}$, それ前述した薬版感受 性の I/D の 3 者亦引耐性薬剤投与の效果を及る己耐性 SMT は E/L, I/D 己も無処置時より大きく, 而性 $\mathrm{Km}$ は E/L は小さいが I/D 注非常に大きく, 耐性 NFTは E/L, I/D とも小さい. すなわち耐性 SMT 投与は有意 義であり，耐性 $\mathrm{Km}$ 投与も無意味でない可能性が強い が，耐性 NFT 投与社有害である可能性が強い，との結 果已耐性発生頻度 (第 7 表) が SMT で97\%，Kmで20 \%, NFT で $83 \%$ あるてと学考あわせると SMT と $\mathrm{Km}$ 核臨床的使用しやすい薬剤であり，NFT 注使用 しにくい薬であるこいう差が明膫である。

非特異性尿路感染症に耐性薬郕学投与するここは必ず しも禁忌でなく, 薬㶡によつては耐性菌尿路感染症に投 与して充分の効果安期待しうるというととになる.

もしかかる事実があるとするならば非特異性尿路感染 症の治療に使用する抗菌性薬成については耐性菌尿路感
染症に投与した場合に無処置時よりも望究しい效果がえ られる可能性が強いか否办学検討して拉くことが臨床的 に極めて重要であるということになる。更に又この様な 見解をもつ々うことは抗菌性薬剂療法の適応注特定の 細菌感染であり, 耐性薬郕投与は禁忌であるという従来 の根本原則空否定することになる。

もしかかる仮定は誤つ\%検査法にもとづく考察で問題 とするに足りないとすると次の様なとと考えねね゙なら ない.すなわちデイスク法による判定はデイスクの規格 が統一されていない為に信頼しえない, 或はデイスクの 規格流一さ統一ているがデイスク法による判定に牥検者 の技術差が多分に加わるので信頼しえない，或はごんな に簃密行つてもデイスク法自体久陥があるので信頼し えない，或はデイスク法惊信頼してもよいが病原菌以外 の菌の薬鼡耐性を検しているのでは無意味である等及々 あげるここが出来る.

臨床的には抗菌性薬剤の選擇は感受性検查の成績にも こづくべきであるといわれており，一般には感受性検查 はデイスク法で行われている。もしデイスク法による判 定がそ沉漂ざ信頼するに足りないものであるならば薬郕 選擇注何学基準として行えばよいのか. 又感染菌のうち から病原菌をえらび出して耐性検查を行わね壮意味がな いというととは正しいのであろう。し亦し特異性感染 症の場合とほ異り非特異性尿路感染症の場合にはとれ注 現在では不可能优いことである.もし非特異性尿路感

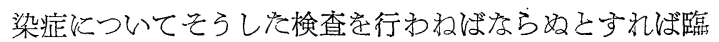
床的には如何なる方法で行えばよいのか。 
要するに耐性菌尿路感染症に耐性薬用学投与すると薬 凨によつては有効なととがあるという仮定に賛成するに しても又反対するにしても，抗菌性薬剤療法に関する従 来の定説について根本的な再検討学行引必要があるこい うここだけ明らかである。

\section{$\mathbf{V}$ 総括及び結語}

奉損患者に合併する非特異性尿路感染症が現在の抗菌 性薬剤療法によつても仲々難治である原因出来るだけ 明確にしょうこい弓意図をもつて脊損患者の尿路感染菌 について行つた細菌学的検查の成績学整理し検討学行つ t.

（1）尿路感染菌皇グラム陰性桿菌とグラム陽性球菌 である・前者について属索での決定学, 後者について種 委での決定定行つた。

（2）尿路感染菌の構成惊 $1 \sim 3$ 週間でも約 $2 / 3$ の症例 で変化し， 4〜6月で全例で変化している.

（3）桿菌己球菌己の混合感染せ60９0\%の症例認 められた。

（4）菌交代の発生頻度無処置群，感性薬鼡投与群 及び耐性薬郕投与群に分けて検すると，何れの群であ菌 交代 $(+)$ の症例数が菌交代（一）の症例数より多 $<$, 全体として菌交代 (一)21例，菌交代 (十)36例であつた。

（5）菌交代の機序学明らかにするここが将来に抬け る重要問題であるととを述べた。

（6）11種の薬剤に対する感受性検查をデイスクによ る直接法で検査した。

（7）11珮中カナマイシン，コリスチン，ストレプト マイシンの 3 剤のみが耐性発生頻度 $60 \%$ 以下であり, 残 る8 戍はすべて $80 \%$ 以上であつた。

（8）11剂中 6 凪以上に耐性な症例は50例中 45 例 $90 \%$ であつた。

（9） 11 剂中 9 郕以上飞耐性の症例は受傷 2 年未满及 び5 年以上では60 80\%であるに反し, 受傷後 $2 \sim 4$ 年 では30 40\%にすぎな. 従つて抗菌性薬荗学受傷後濫 用したために尿路感染菌が漸進的に耐性を獲得してゅく こいう仮定に対しては否定的である。

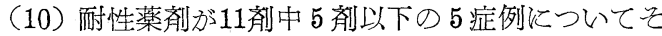
こに至つた経過学みると耐性薬剤数の減少が明らがあ る.

（11）耐性薬郕数の減少が同一細菌の耐性喪失を意味 するか，異つた細菌の感染が扮をたことを意味するかを 検討する目的で菌交代の有無別に成績を己めた。その 結果菌交代 (一) 群の中に演感受性同一の症例は 1 例も なかつたが，菌交代 (十) 群では25\%の症例に沶いて感 受性が同一であつた。

（12）乙の事実を説明するために耐性獲得及び 伝達 に関する考察学行い，現在それに関し定説といわれる mutation \& selection の立場のみでほ不充分であり， 耐性の直接伝達も考慮すべきことを述べた。

（13）耐性薬剂数の増加及び減少学無処置群, 感性薬 鼡投与群及び耐性薬郕投与群と分けて検した。その結果 投与薬郕によりその傾向に差が生じるのではないかて思 われる成績学えた。

（14）耐性薬鼡投与が耐性菌尿路感染症にいかなる意 味をもつか検討した。

（15）投与薬剤の効果は尿中白血球及び細菌の増減办 ら判定した。その結果スルフアメチルチアデアゾールは 耐性菌尿路感染症に投与して有效な可能性が強く, カナ マイシンは無処置時と同程度であり，ニトロフラントイ ンは有害な可能性が強い。すなわ耐性薬郕投与は非特 異性尿路感染症に関しては必ずしも禁忌でなく, 薬剤に よつては有効な可能性が強いとともあることが分つた。

（16）乙の成績定耐性発生率がスルフアメチルチアシ アゾールでは97\%，カナマイシンでは20\%，ニトロフラ

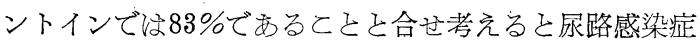
治寮に際しスルフアメチルチアジアゾールとカナマイシ ンは使用しやすいが，ニトロフラントインは使用範囲が ごくせまいということになる。

（17）薬郕によつては耐性菌尿路感染症に投与して有 効な可能性が強いという成績肯定する己抗菌性薬剤療 法関する從来の根本原則を否定するととになり，否定 するるデイスク法による感受性検査法の再檢討或恢中 病原菌の確認方法の確立にいう極めて基礎的な問題の検 討を行わねばならなくなる。要するに感染或怔感染症と

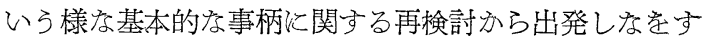
必要があるとと注ごちらの立場をとるにしても避けられ ない。

（本交の要旨は日本泌尿器科学会第25回東部連合地方 会, 第 254 回日本泌尿器科学会東京地方会, 第 259 回日 本泌尿器科学会東京地方会に招いて発表した。

稿を終るに当り検査に協力を扣しまれなかつた臨床検 查室岡本正孝氏及び看護婦諸滖に深く感謝します。）

\section{参考文献}

1) Brauch, Starkey \& Power: Canad. M.A.J., 81, 175, 1959.

2) Cook: Campbell's Urology, p. 503, W.B. Saunders Company, 1957.

3）堂野前, 螺良: 日本医事新報, 1950, 17, 1961.

4) Garrod: Brit. Med. Bull., 16, 23, 1960.

5) Gould: Brit. Med. Bull., 16, 29, 1960.

6) Kass \& Zangwill: Biology of Pyelonephritis, p. 663, Little, Brown \& Company, 1959.

7) 近藤：泌尿紀要, 7, 540, 1961. 